\title{
Enforcing EU environmental policy effectively: international influences, current barriers and possible solutions
}

Citation for published version (APA):

Eliantonio, M. (2016). Enforcing EU environmental policy effectively: international influences, current barriers and possible solutions. In S. Drake, \& M. Smith (Eds.), New directions in the effective enforcement of European law (pp. 175-201). Edward Elgar Publishing. https://doi.org/10.4337/9781784718695.00018

Document status and date:

Published: 01/01/2016

DOI:

10.4337/9781784718695.00018

Document Version:

Publisher's PDF, also known as Version of record

Document license:

Taverne

Please check the document version of this publication:

- A submitted manuscript is the version of the article upon submission and before peer-review. There can be important differences between the submitted version and the official published version of record.

People interested in the research are advised to contact the author for the final version of the publication, or visit the DOI to the publisher's website.

- The final author version and the galley proof are versions of the publication after peer review.

- The final published version features the final layout of the paper including the volume, issue and page numbers.

Link to publication

\footnotetext{
General rights rights.

- You may freely distribute the URL identifying the publication in the public portal. please follow below link for the End User Agreement:

www.umlib.nl/taverne-license

Take down policy

If you believe that this document breaches copyright please contact us at:

repository@maastrichtuniversity.nl

providing details and we will investigate your claim.
}

Copyright and moral rights for the publications made accessible in the public portal are retained by the authors and/or other copyright owners and it is a condition of accessing publications that users recognise and abide by the legal requirements associated with these

- Users may download and print one copy of any publication from the public portal for the purpose of private study or research.

- You may not further distribute the material or use it for any profit-making activity or commercial gain

If the publication is distributed under the terms of Article $25 \mathrm{fa}$ of the Dutch Copyright Act, indicated by the "Taverne" license above, 


\section{Enforcing EU environmental policy effectively: international influences, current barriers and possible solutions}

Mariolina Eliantonio

\section{INTRODUCTION}

The issue of the enforcement of EU environmental law has long been at the top of the EU enforcement agenda ${ }^{1}$ because of the volume of EU environmental legislation ${ }^{2}$ and the serious consequences for humans and nature alike in case of non-compliance. In its 2012 Communication 'Improving the delivery of benefits from EU environment measures: building confidence through better knowledge and responsiveness', the Commission notes that delayed or inadequate implementation of EU environmental legislation 'harms the environment and human health, generates regulatory uncertainty for industry and puts in question the level playing field of the Single Market' ${ }^{3}$ Furthermore, '[t]he long-term remediation costs - for example for clean-up of illegal waste sites and restoration of damaged habitats - can be much higher than the costs of prevention'. ${ }^{4}$ The EU also confirmed in the context of its 2013-20 Environment Action Programme

1 See e.g. Communication from the Commission to the European Parliament, the Council, the European Economic and Social Committee and the Committee of the Regions, 'Improving the delivery of benefits from EU environment measures: building confidence through better knowledge and responsiveness' $\mathrm{COM}(2012)$ 095 final, accessed 10 December 2015 at <http://eur-lex.europa.eu/legal-content/ EN/TXT/?uri=CELEX:52012DC0095>.

2 The Commission reports that the environmental acquis consists of more than 200 legal acts, accessed 8 December 2015 at <http://ec.europa.eu/environment/ legal/law/>.

3 Commission Communication on 'Improving the delivery of benefits from EU environment measures: building confidence through better knowledge and responsiveness' COM(2012) 095 final, n 1, 3.

4 Ibid. 
that implementation and enforcement of EU environmental law should be considered amongst the priority policy objectives for the EU. ${ }^{5}$ In the area of environmental policy, the commitment to better and more effective enforcement of legislation also stems from another layer of governance. The EU is obliged by virtue of international law to ensure that the public has effective means to enforce EU environmental law, through, in particular, ensuring 'wide access to justice', as provided by the UN's Aarhus Convention. ${ }^{6}$

Despite the EU's policy commitments and international obligations, the state of enforcement of EU environmental law is far from satisfactory. The aim of this chapter is to shed some light on the current state of enforcement of EU environmental law and its effectiveness. For the purpose of this analysis, enforcement should be understood as encompassing a range of judicial or extra-judicial mechanisms aimed at ensuring compliance with EU (environmental) rules. The chapter will first focus on the shortcomings of the system of centralized enforcement of environmental law. Thereafter, the chapter will explore the decentralized enforcement system and contextualize this issue within the framework of the Aarhus Convention after having provided some background on the special characteristics of environmental law. As a set of rules often provided for the interest of no one and everyone at the same time, there are unique challenges for the effective enforcement of EU environmental law. The analysis will show how the (private) enforcement of EU environmental law before national courts, which is aimed at repairing the shortcomings of the system of centralized enforcement, also faces several obstacles. The second part of the contribution will focus on some new trends in the enforcement modalities adopted in the field of environmental law, analysing them in the framework of the debate on the 'new' modes of governance. The analysis will demonstrate how the move towards the use of enforcement tools which depart from the traditional commandand-control mechanisms may contribute to more effective enforcement of environmental law.

5 Dec 1386/2013 of the European Parliament and of the Council on a General Union Environment Action Programme to 2020 'Living well, within the limits of our planet' [2013] OJ L354/171.

6 United Nations Economic Commission for Europe, Convention on Access to Information, Public Participation in Decision-Making and Access to Justice in Environmental Matters, accessed 8 December 2015 at $<\mathrm{http}$ ///www.unece.org/ fileadmin/DAM/env/pp/documents/cep43e.pdf>. 


\section{CENTRALIZED ENFORCEMENT OF EU LAW IN THE CONTEXT OF ENVIRONMENTAL POLICY AND ITS LIMITATIONS}

Over the past 30 years the EU has adopted a substantial and diverse range of environmental measures. Some legislation is sector specific covering water, air, nature, waste, noise and chemicals. Other measures are horizontal in nature and cut across all environmental sectors, for example, environmental impact assessments, access to environmental information, public participation in environmental decision-making and liability for environmental damage. The vast majority of these rules follow a typical command-andcontrol system in that they contain binding rules (very often in the form of directives) which provide judicially enforceable prohibitions. Furthermore, most environmental measures are implemented following the model of 'indirect administration', 7 whereby it is for Member State authorities to implement the EU measures in accordance with their national administrative framework subject to EU standards set out by the CJEU (principles of equivalence, effectiveness and effective judicial protection) and Article 47 of the Charter of Fundamental Rights of the European Union. ${ }^{8}$

The implementation of EU environmental law, that is to say the process of translating policy into action, ${ }^{9}$ entails several stages, namely transposition into national law including the notification of the transposing measures to the Commission (phases which are necessary for directives only), the setting up of a legal and administrative framework for the proper application and enforcement of EU legislation (often referred to as the operationalization stage), its practical application to concrete cases and its enforcement. ${ }^{10}$ All of these stages are to be overseen by the Commission fulfilling its role as 'guardian of the Treaties' in accordance with Article 17(1) TEU. The main enforcement mechanism available to the Commission in performing this function is set out in Article 258 TFEU, through which

7 See further, Herwig C.H. Hofmann, Gerard C. Rowe and Alexander H. Türk, Administrative Law and Policy of the European Union (Oxford University Press 2011) $12 \mathrm{ff}$.

8 Case 33/76 Rewe [1976] ECR 1989 and case C-45/76 Comet [1976] ECR 2043; C-432/05 Unibet Ltd [2007] ECR I-2271; case C-279/09 DEB [2010] ECR I-13849. For further discussion, see Chapter 1 in this volume.

9 Susan M. Barret, 'Implementation Studies: Time for a Revival? Personal Reflections on 20 Years of Implementation Studies' (2004) Pub Adm 251.

10 Koen Lenaerts and José Gutiérrez-Fons, 'The General System of EU Environmental Law Enforcement' (2011) YEL 3-4; Jan Jans, Sacha Prechal and Rob Widdershoven, Europeanisation of Public Law (Europa Law Publishing 2007) $13 \mathrm{ff}$. 
the Commission has the right to open infringement procedures against a Member State for failing to comply with its environmental obligations and can eventually bring the non-compliant Member State before the CJEU. ${ }^{11}$ The Commission is able to pursue Member State non-compliance with any Article 258 TFEU rulings of the CJEU through the imposition of financial sanctions as set out in Article 260 TFEU. Environmental law has played a prominent place in such proceedings with an environmental case being the first ever Article 260 TFEU proceeding started by the Commission. ${ }^{12}$

The pursuit of infringements for breach of environmental law under Article 258 TFEU is certainly at the top of the Commission's infringement list. In 2013, environment was once again the policy area where most infringement proceedings were initiated ${ }^{13}$ reflecting a worrisome trend. ${ }^{14}$ Specifically in the field of environmental law, the CJEU has accepted the Commission's argument that the subject matter of infringement proceedings may be 'systemic deficient administrative practices' thereby creating the concept of 'general and persistent breach' (GAP breach). This approach enables the Commission to speed up and render infringement proceedings more efficient because it enables the Commission to bundle recurrent and systemic breaches into one single procedure. ${ }^{15}$ The significant improvement brought about by the GAP system lies thus in the effects of a GAP ruling vis-à-vis the 'regular' infringement proceedings. Whilst in a 'regular' infringement case, the Member State is obliged only to take the necessary measures to address the specific breaches at stake, the consequence of a GAP judgment is that the national authorities must rectify the specific infringements and correct the administrative practice in place so that subsequent infringements do not occur. ${ }^{16}$

11 For more detailed analysis of the Commission's use of Article 258 TFEU in the enforcement of EU law, see Chapter 2 in this volume.

12 C-387/97 Commission v Greece [2000] ECR I-5047.

13 Report from the Commission, 31st Annual Report on Monitoring the Application of EU Law (2013) COM(2014) 612 final, 12, accessed 10 December 2015 at <http://ec.europa.eu/atwork/applying-eu-law/docs/annual_report_31/ com_2014_612_en.pdf>.

${ }_{14}$ Report from the Commission, 30th Annual Report on Monitoring the Application of EU Law (2012) COM(2013) 726 final, accessed 8 December 2015 at <http://eur-lex.europa.eu/legal-content/EN/TXT/?uri=COM:2013:726:FIN 8 December 2015>.

15 See case C-494/01 Commission v Ireland [2005] I-03331. See further on this point, Pål Wennerås, 'A New Dawn for Commission Enforcement under Articles 226 and 228 EC: General and Persistent (GAP) Infringements, Lump Sums and Penalty Payments' (2006) CMLRev 31.

16 Ibid at $42-3$. 
Despite the Commission's efforts to monitor the implementation of EU environmental law and to pursue infringements, and despite the improvements brought about by the creation of the concept of 'general and persistent breach' in environmental matters, there are several shortcomings with this centralized model of enforcement which are well known, but can have particular resonance in the field of environmental policy. First, the Commission does not have the capacity to exercise a proper monitoring system when the application (rather than the transposition) of EU environmental legislation is concerned. Whereas the Commission is able to obtain precise information on the national measures adopted for the transposition of directives, the practical application of EU legislation has been referred to as 'exceedingly difficult to monitor and to evaluate'.${ }^{17}$ Extensive legal and political research has confirmed that the lack of direct investigative and oversight powers, ${ }^{18}$ and overoptimistic reliance on Member States' self-reporting powers ${ }^{19}$ and civil society complaint activities ${ }^{20}$ renders the Commission incapable of detecting all instances of non-compliance with EU legislation. ${ }^{21}$ This undoubtedly leaves several instances of non- or incorrect application of EU environmental law undetected. Second, if detected, infringement proceedings under Article 258 TFEU are initiated at the full discretion of the Commission. The CJEU has granted some leeway for the Commission in its case law when it comes to deciding whether or not ${ }^{22}$ and when ${ }^{23}$ to start infringement proceedings (and whether or not, and when, to refer a case to the Court). ${ }^{24}$ When this discretion is viewed in combination with the Commission's shift

17 Jonas Tallberg, 'Paths to Compliance: Enforcement, Management, and the European Union' (2002) IO 624.

18 Brian Jack, 'Enforcing Member State Compliance with EU Environmental Law: A Critical Evaluation of the Use of Financial Penalties' (2011) JEL 76; Martin Hedemann-Robinson, Enforcement of European Union Environmental Law: Legal Issues and Challenges (Routledge 2007) 161-4.

19 Peter Van den Bossche, 'In Search of Remedies for Non-Compliance: The Experience of the European Community' (1996) MJ 389.

20 Tanja Börzel, 'Non-Compliance in the European Union: Pathology or Statistical Artefact?' (2001) JEPP 809-10.

${ }_{21}$ See e.g. Gerda Falkner, Oliver Treib, Miriam Hartlapp and Simone Leiber, Complying with Europe: EU Harmonization and Soft Law in the Member States (Cambridge University Press 2005); Tanja Börzel, Tobias Hofmann, Diana Panke and Carina Sprungk, 'Obstinate and Inefficient: Why Member States Do Not Comply with European Law' (2010) Comp Pol Stud 1363-90.

22 Case 247/87 Starfruit v Commission [1989] ECR 291.

23 Case 7/68 Commission v Italy [1968] ECR 423, 428.

24 See e.g. case C-562/07 Commission v Spain [2009] ECR I-9553. The doctrine talks about the principle of selective enforcement. Hofmann, Rowe and Türk, Administrative Law and Policy of the European Union, n 7, 748. 
towards a clear prioritization of certain types of infringements ${ }^{25}$ (which, in the environmental field, entails pursuing 'only' serious breaches of EU environmental legislation in addition to non-communication of transposition measures and Article 260 TFEU cases), ${ }^{26}$ serious questions about the effectiveness of the centralized mechanism for enforcement may be raised. Third, the effectiveness of infringement proceedings can be limited by the excessive length of the proceedings. This can be particularly problematic in this policy area as environmental damage cannot always be undone. In earlier research Hedemann-Robinson noted that on average the time between notification of the letter of formal notice to the defaulting Member State and the notification of the judgment of the CJEU amounts to six years. ${ }^{27}$ The length of proceedings may be extended if there is a need to instigate second round infringement proceedings under Article 260 TFEU. ${ }^{28}$ The lapse of time may therefore create environmental damage which may be impossible to repair. Interim measures play a 'relatively limited' (though increasingly relevant) role in relation to environmental infringement actions. ${ }^{29}$

25 Communication from the Commission, 'A Europe of results: applying Community law' COM(2007) 502 final, accessed 10 December 2015 at $<$ http://eur-lex. europa.eu/resource.html?uri=cellar:6fclad14-7018-485f-bceb-ab767b5c5927.0003. 02/DOC_3\&format=PDF $>$.

26 Communication from the Commission to the European Parliament, the Council, the European Economic and Social Committee and the Committee of the Regions, 'Implementing European Community environmental law' COM(2008) 773 final, accessed 10 December 2015 at <http://eur-lex.europa.eu/legal-content/ $\mathrm{EN} / \mathrm{TXT} / \mathrm{PDF} /$ ?uri=CELEX:52008DC0773\&from $=\mathrm{EN}>$. See further on this point, Susanne Kingston, 'Mind the Gap: Difficulties in Enforcement and the Continuing Unfulfilled Promise of EU Environmental Law', in Susanne Kingston (Ed.), European Perspectives on Environmental Law and Governance (Routledge 2013) 149-50.

27 Hedemann-Robinson, Enforcement of European Union Environmental Law: Legal Issues and Challenges, n 18, 168. The period prior to sending the formal notice has now been formalized in the EU Pilot and as a consequence the previously indeterminate time for Commission-Member State negotiations is now limited in most cases to 20 weeks, significantly speeding up the amount of time taken to process infringement cases, see Chapter 2 of this volume.

28 Hedemann-Robinson has assessed that as at the end of 2006 the average length of second round proceedings under Article 228(2) EC (the predecessor to Article 260(2) TFEU) was approximately 13 years: see Martin HedemannRobinson, 'Article 228(2) EC and the Enforcement of EC Environmental Law: A Case of Environmental Justice Delayed and Denied? An Analysis of Recent Legal Developments' (2006) EELR 317. However, this has now been shortened considerably since the introduction of the Lisbon reforms which removes the requirement of the reasoned opinion stage under Article 260(2).

29 Martin Hedemann-Robinson, 'Enforcement of EU Environmental Law and the Role of Interim Relief Measures' (2010) EEELR 204. 
All in all, it can be concluded that the road to an effective centralized enforcement of EU environmental law is paved with several obstacles, linked to the limited investigative capacity of the Commission, its selective infringement policy and the duration of the infringement proceedings. As will be shown below, the decentralized enforcement system cannot, as of today, fully compensate for these shortcomings.

\section{EFFECTIVE DECENTRALIZED ENFORCEMENT AND ACCOMMODATING THE DISTINCT NATURE OF EU ENVIRONMENTAL LAW}

The shortcomings of the centralized enforcement system render it of utmost importance for the EU to be able to rely on private litigation before the national courts to effectively enforce EU environmental legislation. ${ }^{30}$ This has long been emphasized by the Commission itself. ${ }^{31}$ National courts, however, are only able to intervene and repair instances of non-compliance when cases are brought before them by litigants and when the violation of EU environmental law can be successfully pleaded before them. In cases involving the infringement of EU environmental law, this is far from self-evident. Environmental law embodies certain features which can restrict the avenues of enforcement available for litigants and can also impair effective control by national courts. Furthermore, there are limitations encumbent in national standing rules and the implementation of the Aarhus Convention as well as the requirements imposed by the EU doctrines of direct effect and state liability.

30 Please note that EU environmental law can be violated also by EU institutions. In such cases, private applicants are entitled to bring annulment proceedings according to Article 263 TFEU. This topic falls outside the scope of this contribution. For an extensive overview of the shortcomings of annulment proceedings in environmental matters, see Mariolina Eliantonio, 'Towards an Ever Dirtier Europe? The Restrictive Standing of Environmental NGOs before the European Courts and the Aarhus Convention' (2011) CYELP 69.

31 The reliance of the EU on decentralized enforcement before the national courts has long been recognized as a necessary part of its enforcement strategy. In a 1996 Communication, the Commission reflected openly for the first time on the limited role and impact that infringement proceedings could have in relation to the enforcement of EU environmental law. In this light, in the Communication, the Commission chose to emphasize that it should prioritize its focus on infringements of long-term strategic importance, namely non-communication and non-conformity cases. Communication from the Commission, 'Implementing environmental law' COM(1996) 500 final. 


\subsection{National Standing Rules and the Aarhus Convention: Securing 'Access to Justice'}

The conception of the environment as a 'common good' and the rules aimed at protecting the environment, which provide for the interest of no one and everyone at the same time, have led to difficulties in enforcing EU environmental law before national courts. In 2011, the European Commission stated that '[e]ffective enforcement of EU law is of utmost importance for citizens and businesses alike' and that ' $r$ rights which cannot be enforced in practice are worthless. Where substantive EU rights are infringed, citizens and businesses must be able to enforce the rights granted to them by EU legislation.' ${ }^{32}$

However, the need to preserve and strive for the effective enforcement of EU law seems to presuppose the existence of a 'substantive EU right' which has been violated by the national authorities (or by private parties). This requirement is certainly not excluded in environmental matters, ${ }^{33}$ but fulfilling it is problematic in this policy field due to the nature of environmental law itself. The vast majority of environmental measures (such as those contained in the Habitats Directive ${ }^{34}$ and the Birds Directive) ${ }^{35}$ protect interests of a diffuse nature rather than individual rights or interests. In general, such measures do not confer any rights on individuals but serve the collective public interest in the protection of biodiversity. ${ }^{36} \mathrm{In}$ such cases, according to the applicable national procedural rules, there is no one party who will have standing before a national court ${ }^{37}$ as nobody

32 Commission Staff Working Document, 'Towards a Coherent European Approach to Collective Redress' SEC(2011) 173 final, 1, accessed 10 December 2015 at <http://ec.europa.eu/dgs/health_consumer/dgs_consultations/ca/docs/ cr_consultation_paper_en.pdf $>$.

33 See e.g. on air quality, case C-237/07 Janecek [2008] ECR I-6221.

34 Dir $92 / 43$ of 21 May 1992 on the conservation of natural habitats and of wild fauna and flora [1992] OJ L206/7.

35 Dir 2009/147 of the European Parliament and of the Council of 30 November 2009 on the conservation of wild birds [2010] OJ L20/7.

36 See further on this point, Chris Backes and Mariolina Eliantonio, 'Access to Courts for Environmental NGOs at European and National Level: What Improvements and What Room for Improvement since Maastricht?', in Maartje de Visser and Anne-Pieter van der Mei (Eds), The Treaty on European Union 1993-2013: Reflections from Maastricht (Intersentia 2013) 559-60.

37 That, is, excluding the rare cases of legal systems offering the possibility of an actio popularis, i.e. where anyone can bring a claim against the actions of public authorities without showing that his or her rights or interests have been violated. This possibility is very limited, and, as comparative research has shown, almost non-existent in environmental matters with some notable exceptions, such 
can prove an infringement of his or her rights or interests by a public authority. In view of this characteristic of environmental law, the role of non-governmental organizations (NGOs) is of fundamental importance. It follows that the effectiveness of the enforcement of EU environmental law is highly dependent on the ability of environmental NGOs to bring claims for alleged violations of environmental provisions before national courts. ${ }^{38}$

The Aarhus Convention, ${ }^{39}$ a UN Convention, ${ }^{40}$ was drafted in order to enhance the possibilities for environmental NGOs to supplement the lack of interest or ability of citizens to bring environmental claims before national courts and enable them to take action against infringements of environmental law. The Convention is structured around three main pillars: access to information, public participation and access to justice in environmental matters. It binds not only the EU, but also the Member States when they are acting within the scope of application of EU law. ${ }^{41}$ In assessing the effective enforcement of environmental law, it is necessary to focus on the access to justice pillar and its two key provisions: Article 9(2) provides that the contracting parties should ensure that concerned members of the public with a qualified interest ${ }^{42}$ have access to a review

as the case of Portugal. See further, Mariolina Eliantonio, Chris Backes, C.H. van Rhee, Taru Spronken and Anna Berlee, Standing Up for Your Right(s) in Europe (Intersentia 2012) Section 4.6, 69-70, accessed 10 December 2015 at <http:// www.europarl.europa.eu/committees/fr/studiesdownload.html?languageDocume $\mathrm{nt}=\mathrm{EN} \&$ file $=75651>$; Sophie Roussel and Olivier Fuchs, 'Accès Des Citoyens à La Justice et Organisations Juridictionnelles en Matière d'Environnement, Spécificités Nationales et Influences du Droit de l'union Européenne: Rapport General', 8, accessed 10 December 2015 at <http://www.aca-europe.eu/seminars/ Bruxelles2012/Rapport_general.pdf>.

38 That is, if one excludes the possibility of a public prosecutor, ombudsman or other public authority in charge of pursuing environmental violations in the public interest.

39 See $n 6$.

40 Specifically it was developed within the United Nations Economic Commission for Europe (UNECE).

41 The Convention was adopted by the then European Community on 17 February 2005 by Dec 2005/370 on the conclusion, on behalf of the European Community, of the Convention on access to information, public participation in decision-making and access to justice in environmental matters [2005] OJ L124/1. It should also be added that, since all the Member States have ratified the Aarhus Convention, this international instrument is binding on them outside the scope of application of EU law as well. However, in such cases, the effect of the Convention within the legal order of the Member States is dependent upon their constitutional orders.

42 That is, either (1) a sufficient interest or (2) maintaining impairment of a right (where the administrative procedural law of a state requires this as a precondition). 
procedure to challenge the substantive and procedural legality of decisions concerning projects which can have a significant environmental impact; Article 9(3) imposes a general obligation on the signatories to provide wide access for the public to access review procedures to challenge the legality of all kinds of decisions affecting the environment. ${ }^{43}$

\subsubsection{Article 9(2) Aarhus Convention}

The EU has taken steps to align Member States' legislation with Article 9(2) through the enactment of Directive 2003/35/EC. ${ }^{44}$ Like the Convention, the Directive proposes two models of access to justice and allows the Member States the option of choosing whether to grant standing for the "public concerned' where an applicant can show the impairment of a right or when it is able to show a sufficient interest. For both these options, the Directive mandates that the national rules on standing must be consistent with the overall objective of giving the public concerned wide access to justice. To this end, any NGO promoting environmental interests and meeting any standing requirements under national law shall be deemed as capable of showing sufficient interest. Such organizations shall also be deemed to have rights capable of being impaired in a legal system that has opted for a rights-based approach. The freedom of Member States to choose a standing regime

43 See further on Article 9 of the Aarhus Convention, Luc Lavrysen, 'The Aarhus Convention: Between Environmental Protection and Human Rights', in Paul Martens, Marc Bossuyt, Marie-Francoise Rigaux, Bernadette Renauld (Eds), Liber amicorum Michel Melchior (Anthemis 2010) 663; Jerzy Jendroska, 'Accès à la justice: remarque sur le statut juridique et le champ des obligations de la convention d'Aarhus dans le contexte de l'Union Européenne' (2009) RJE Special Issue 31; Thomas von Danwitz, 'Aarhus Konvention: Umweltinformation, Öffentlichkeitsbeteiligung, Zugang zu den Gerichten' (2004) Neue Zeitschrift für Verwaltungsrecht 272; Martin Hedemann-Robinson, 'EU Implementation of the Aarhus Convention's Third Pillar: Back to the Future over Access to Environmental Justice? Part 1' (2014) EEELR 102.

44 Dir 2003/35/EC of the European Parliament and of the Council of 26 May 2003 providing for public participation in respect of the drawing up of certain plans and programmes relating to the environment and amending with regard to public participation and access to justice [2003] OJ L156/17. This Directive amended two other Directives. On this point, see Birgit Dette, 'The Aarhus Convention and Legislative Initiatives for its Implementation', in Thomas Ormond, Martin Führ and Regine Barth (Eds), Liber amicorum Betty Gebers (Lexxion 2006) 63. Further on the interplay between the Aarhus Convention and EU law, Jonas Ebbeson, 'Access to Justice at the National Level: Impact of the Aarhus Convention and European Union Law', in Marc Pallemaerts (Ed.), The Aarhus Convention at Ten: Interactions and Tensions between Conventional International Law and EU Environmental Law (Europa Law Publishing 2011) 247. 
creating a more or less limited enforcement framework for NGOs in environmental matters is thus limited by the overarching requirement to ensure wide access to justice. However, Directive 2003/35 only applies to procedural rules concerning legal actions brought against projects which can have a significant environmental impact. It does not apply to all other environmental measures such as measures taken for the protection of an endangered species under the Habitats Directive or permits to discharge waste water.

The transposition of Article 9(2) of the Aarhus Convention through Directive 2003/35 has been in general rather smooth. Recent comparative research by legal scholars including this author has shown that these provisions have been correctly transposed in most of the Member States examined. In the majority of the nine EU legal systems surveyed, the legislation on access to justice was amended in order to adequately transpose the Directive or the existing law has been interpreted by the courts in such a way as to ensure compliance with the Aarhus Convention and Directive 2003/35. ${ }^{45}$ However, there are also Member States in which the legislation and case law has not been changed because the Member States in question are convinced that their national law is already compliant. For some Member States such as France and Italy, the outcome of this assessment may be correct. For some other legal systems such as Poland, Germany and Belgium, it is either doubtful whether they currently meet the requirements of the Convention, or it is very likely that they do not. ${ }^{46}$ Finally, some Member States are evidently in breach. Indeed, their national legislation has been declared by the CJEU to be in breach of Directive 2003/35 (and, therefore, indirectly, Article 9(2) of the Aarhus Convention). The most prominent example being Germany. In all cases where issues of non or incorrect implementation of the Directive have been referred to the CJEU, ${ }^{47}$ the national legislation has been subsequently amended in order to comply with the EU requirements. ${ }^{48}$

45 See further Mariolina Eliantonio, Chris Backes, C.H. van Rhee, Taru Spronken and Anna Berlee, Standing Up for Your Right (s) in Europe, n 37, Sections 4.7.4 and 4.10.1; Sophie Roussel and Olivier Fuchs, 'Accès Des Citoyens à La Justice et Organisations Juridictionnelles en Matière d'Environnement, Spécificités Nationales et Influences du Droit de l'union Européenne: Rapport General', n 37, 16-17.

46 Ibid.

47 Case C-263/08 Djurgården-Lilla Värtans Miljöskyddsförening v Stockholms kommun genom dess marknämnd [2009] ECR I-9967. For a comment on this case, see Ainé Ryall, 'Comment to Djurgården' (2010) CMLRev 1511. Case C-115/09 Bund für Umwelt und Naturschutz Deutschland, Landesverband NordrheinWestfalen eV v Bezirksregierung Arnsberg [2001] ECR I-3673.

48 For Sweden see $\S 13$, Chapter 6, Miljöbalk (1998:808) accessed 10 December 2015 at <http://www.notisum.se/rnp/sls/lag/19980808.HTM>. For Germany, see 


\subsubsection{Article 9(3) Aarhus Convention}

A more general provision on access to justice covering all environmental matters, and not just those of significant impact, transposing the requirements of Article 9(3), is currently lacking. In 2003, the Commission presented a Proposal for a Directive of the European Parliament and of the Council on access to justice in environmental matters ${ }^{49}$ which would give effect to Article 9(3) of the Convention. The Directive has not been adopted to date on the ground that 'Member States remained unconvinced that legislative action at EU level was needed to implement Article 9(3) ${ }^{50}$ and that the proposal was overly intrusive into the national judicial systems of the Member States. ${ }^{51}$ Since 2012 the Commission has been preparing a new proposal for a directive which takes the legal situation in the Member States and the recent case law of the CJEU into account. ${ }^{52}$

Meanwhile, in the absence of EU harmonizing measures giving effect to Article 9(3), the CJEU has been required to determine whether Article 9(3) could be directly relied upon by individuals before national courts. ${ }^{53}$ In its $2011 V L K$ case, a preliminary ruling submitted by a Slovakian court, the Court denied direct effect to this provision arguing that it was not sufficiently precise and unconditional. However, it added that national courts had a duty to interpret their national law in a way which is to the fullest

the ruling of the Higher Administrative Court of Muenster, 1 December 2011, 8 D 58/09 AK; and the ruling of the Higher Administrative Court of Mannheim, 20 July 2011, 10 S 2102/09. Legislative amendment: BGB1. I, 95. See further, Mariolina Eliantonio, 'Collective Redress in Environmental Matters in the EU: A Role Model or a "Problem Child”?' (2014) LIEI 257-73.

49 Proposal for a Directive of the European Parliament and of the Council on access to justice in environmental matters, $\operatorname{COM(2003)} 624$ final.

50 European Commission, 'Explanatory Consultation Document', 2, accessed 10 December 2015 at <http://ec.europa.eu/environment/consultations/pdf/access. pdf>.

51 European Commission, 'Roadmap, Commission Initiative on Access to Justice in Environmental Matters at Member State Level in the Field of EU Environment Policy', 1, accessed 10 December at <http://ec.europa.eu/smart-regulation/impact/ planned_ia/docs/2013_env_013_access_to_justice_en.pdf $>$.

52 The Commission has undertaken a number of studies: European Commission, 'The Aarhus Convention: 2012/2013 Access to Justice Studies', accessed 10 December 2015 at <http://ec.europa.eu/environment/aarhus/access_ studies.htm>.

53 Case C-240/09 Lesoochranárske zoskupenie VLK v Ministerstvo životného prostredia Slovenskej republiky [2011] ECR I-1255. For a comment on this case, as well as the Trianel ruling discussed above, see Mariolina Eliantonio, 'Case C-240/09 Lesoochranárske zoskupenie VLK v. Ministerstvo životného prostredia Slovenskej republiky, Judgment of the Court of Justice (Grand Chamber) of 8 March 2011' (2012) CMLRev 767. 
extent possible consistent with the objectives laid down in Article 9(3) of the Aarhus Convention. As a consequence of this ruling, the referring court, by way of consistent interpretation (or indirect effect), admitted the NGO as a party to the proceedings. ${ }^{54}$ This approach has been followed by national courts in other Member States. ${ }^{55}$ In general, this ruling implies that national courts are under the duty to test all the requirements for access to court for NGOs against Article 9(3) of the Aarhus Convention and, if necessary, allow claims by NGOs in environmental matters even where national rules on standing would not allow it. While this development can be considered as a positive step towards achieving compliance with the standards set by the Aarhus Convention and in improving the effective enforcement of EU environmental law, it cannot be overstated that it may also bring about a certain degree of uncertainty. Potentially, there could be wide differences in the assessments of the courts of 28 Member States as to whether their national procedural standards are in compliance with Article 9(3).

In the aftermath of the case law on Article 9(3) and the potential state of uncertainty it could bring about, the Commission is very keen on promoting a new legislative agenda. In the 2012 Communication, the Commission explicitly referred to the Court's case law and reminded national courts of their duty of consistent interpretation. ${ }^{56}$ Furthermore, the Commission has launched a series of initiatives including a public consultation ${ }^{57}$ in order to prepare the ground for a possible legislative initiative. In particular, a study conducted under the direction of Jan Darpö discussed four options which the Commission had brought forward to consider for future actions. ${ }^{58}$ The first option would be to enact a directive on access to justice

54 These cases can be found with numbers 3Sžp/49/2009, 3Sžp/50/2009, 3Sžp/48/2009 and 3Sžp/47/2009 on the website of the Supreme Court of the Slovak Republic, accessed 10 December 2015 at <http://www.supcourt.gov.sk/rozhod nutia $>$. The role of the doctrine of indirect effect in the private enforcement of EU law is discussed in more detail in Chapter 1 of this volume.

55 For Germany, see the ruling of the Lower Administrative Court of Wiesbaden, 10 October 2011, 4 K 757/11 and the ruling of the Lower Administrative Court of Augsburg, 13 February 2013, Au 2 S 13.143. See for a Finnish case, the ruling of the Finnish Supreme Administrative Court n. 49/2011, accessed 10 December 2015 at <http://www.finlex.fi/fi/oikeus/kho/vuosikirjat/2011/201101 351 ? search[type] $=$ pika\&search[pika] $=2011 \% 3 \mathrm{~A} 49>$.

56 Commission Communication on 'Improving the delivery of benefits from EU environment Measures: building confidence through better knowledge and responsiveness' COM(2012) 095 final, n 1, 9.

57 Accessed 10 December 2015 at <http://ec.europa.eu/environment/aarhus/ consultations.htm>.

58 Jan Darpö, 'Effective Justice? Synthesis Report of the Study on the Implementation of Articles 9.3 and 9.4 of the Aarhus Convention in Seventeen 
reflecting the legal regime of the Member States concerning NGO standing and the recent case law of the CJEU which essentially mirrors Directive 2003/35 with regard to Article 9(2). The second option was to reiterate the old proposal which had stalled in the Council since 2003..$^{59}$ Third, it proposed using soft law instruments to promote collaboration between national courts possibly supplemented by Commission guidelines explaining the significance and implications of the case law. Finally, it suggested using infringement proceedings as a tool to promote compliance with the requirements of the CJEU's case law.

It is argued that the study rightfully concluded that a legislative measure should be adopted. It deemed it the most effective way of achieving the aims set out in Article 9(3) and ensuring the effective enforcement of EU environmental law. In particular, the study considered that the 'soft law' option would leave national differences intact and would not provide any incentive for Member States to comply with CJEU case law. The infringement proceedings option would be too time and resource consuming and would not ensure the necessary uniformity. Furthermore, neither of these options are considered to guarantee a sufficient level of legal certainty and a level playing field for NGOs throughout the EU. ${ }^{60}$ As a next step, the Commission has produced a roadmap document for the purposes of an impact assessment review. ${ }^{61}$ The roadmap is subject to ongoing review and awaiting formal approval. ${ }^{62}$

Given the legal uncertainty generated by the lack of transposition of Article 9(3) and the unsuitability of the alternative mechanisms (i.e. the use of soft law for streamlining national procedural standards or infringement proceedings), it is certainly desirable to set common EU criteria for

of the Member States of the European Union' (2012) accessed 10 December 2015 at <http://ec.europa.eu/environment/aarhus/pdf/synthesis $\% 20$ report $\% 20$ on $\% 20$ access $\% 20$ to $\% 20$ justice.pdf $>$. New link: <http://ec.europa.eu/environment/ aarhus/pdf $/$ synthesis $\% 20$ report $\% 20$ on $\% 20$ access $\% 20$ to $\% 20$ justice.pdf $>$.

59 For the difference between these two options, see ibid, 24.

60 Ibid, 23. Please note that this preference also seems to be shared by those who participated in the public consultation launched by the Commission on this theme: <http://ec.europa.eu/yourvoice/ipm/forms/dispatch?userstate=DisplayPu blishedResults\&form=A2JUST $>$ accessed 10 December 2015 (see in particular under question 12(c)).

61 European Commission, 'Roadmap, Commission Initiative on Access to Justice in Environmental Matters at Member State Level in the Field of EU Environment Policy', n 51.

62 See European Commission, Roadmaps $2014<\mathrm{http}$ //ec.europa.eu/smartregulation/impact/planned_ia/roadmaps_2014_en.htm\#ENV $>$ accessed 10 December 2015. 
NGO standing. Having different national procedural rules may create divergent results when national courts apply the same EU environmental provision endangering the effective enforcement of EU environmental law. Furthermore, the Commission indicates that the current state of uncertainty raises a number of further problems. First, there is a failure to maximize the benefits of environmental legislation and potential non-compliance with EU law. Second, this in turn may create market distortions of competition and a lack of legal certainty for investments. Finally, a growing number of complaints which are not resolved at national level will lead to complaints overwhelming the Commission who is seen as the final enforcer of EU law. ${ }^{63}$

The analysis carried out above shows that the effectiveness of decentralized enforcement of EU environmental law requires environmental NGOs to have access to court and to be able to engage in litigation. The possibility to do so has been enhanced by the EU ratification of the UN Aarhus Convention, but is undermined by the fact that it has not been fully transposed at the EU level. Whilst Article 9(2) has been generally well transposed, Article 9(3) has not been transposed yet, leaving national courts with the task of interpreting their standing rules in such a way as to ensure an effective enforcement of EU environmental law. The Commission is currently in the process of finalizing a proposal on a new directive on access to justice, the destiny of which remains uncertain.

\subsection{Private Enforcement of EU Environmental Law: The Limitations of Direct Effect and State Liability}

The nature of environmental law and its aim to protect diffuse (rather than individual) interests results in a lack of standing for individuals in a great number of cases where there is a breach and in the necessary reliance on environmental NGOs to promote the effective enforcement of EU environmental law. However, even when access to court is gained by individuals or associations, further constitutional hurdles present themselves.

The doctrine of direct effect gives individuals the possibility to enforce before national courts the rights granted to them by EU law. ${ }^{64}$ However, most provisions of environmental law are not intended to confer rights on individuals and therefore an orthodox application of the notion of direct effect can bar private applicants from relying on EU environmental law

63 European Commission, 'Roadmap, Commission Initiative on Access to Justice in Environmental Matters at Member State Level in the Field of EU Environment Policy', n 51, 3.

64 Case 26/62 van Gend en Loos [1963] ECR-1. 
before national courts. ${ }^{65}$ However, some scholars have considered that direct effect should prescind from the existence of a right. ${ }^{66}$ This interpretation is justified by the need to ensure an effective enforcement of EU law in light of the nature of environmental law and is to a certain extent supported by the CJEU's case law. In its Kraaijeveld ${ }^{67}$ and Linster ${ }^{68}$ judgments, the Court seems to have detached direct effect from the existence of a right and given individuals the possibility of enforcing legal duties enshrined in environmental provisions intended to benefit the public interest. ${ }^{69}$ This allows a provision of EU law to be regarded as having direct effect if it is sufficiently precise and unconditional in its wording. ${ }^{70}$ Such a development could certainly be seen as favouring the effective enforcement of EU environmental law since it seems to create, as some authors have suggested, a 'public interest effect' whereby individuals are allowed to rely on EU law provisions for the collective interest. ${ }^{71}$ However, because many provisions in the environmental field impose only broad obligations on the national authorities, few norms in this area fulfil the precision and unconditionality criteria. ${ }^{72}$ This often leaves applicants without the possibility of pleading the violation of EU environmental law before their national courts.

In addition, the nature of environmental law and its aim to protect diffuse interests may prove a hurdle for the purpose of state liability actions. As is well known, the first condition to be fulfilled by an individual seeking to hold a Member State liable in damages for the violation of EU law is that the relevant provision must be intended to confer rights on an individual. ${ }^{73}$ This hurdle may prove insurmountable in many environmental cases. Accordingly, Prechal and Hancher have argued that:

65 See further, Pål Wennerås, The Enforcement of EC Environmental Law (Oxford University Press 2007) 18.

66 Sacha Prechal and Leigh Hancher, 'Individual Environmental Rights: Conceptual Pollution in EU Environmental Law?' (2012) YEEL 98.

67 Case C-72/95 Kraaijeveld [1996] ECR I-5403.

68 Case C-287/98 Linster [2000] ECR I-6917.

69 Hedemann-Robinson, Enforcement of European Union Environmental Law: Legal Issues and Challenges, n 18, $241 \mathrm{ff}$.

70 Jan H. Jans and Hans H.B. Vedder, European Environmental Law (3rd edition, Europa Law Publishing 2008) 170-71.

71 Prechal and Hancher, n 66, 89.

72 See e.g. the case C-236/92 Comitato di Coordinamento per la Difesa della Cava and others $v$ Regione Lombardia and others [1994] ECR I-483 and the further discussion in Hedemann-Robinson, Enforcement of European Union Environmental Law: Legal Issues and Challenges, n 18, $225 \mathrm{ff}$.

73 Joined cases C-46/93 and C-48/93 Brasserie du Pêcheur SA v Bundesrepublik Deutschland and The Queen $v$ Secretary of State for Transport, ex parte: Factortame Ltd and others [1996] ECR I-1029. 
as long as liability and injunctions are linked to the issue of infringement of an individual right [.. .] these remedies will not necessarily work for directives which seek to protect general environmental interest, as for example in the field of habitat protection. ${ }^{74}$

There is some support in the case law of the Court that this rights-based approach to liability has been modified. In its Wells ${ }^{75}$ judgment, the EU environmental provision at stake (concerning the environmental impact assessment procedure) clearly did not confer rights on individuals. In addition to granting direct effect, the CJEU also held that an individual may be entitled to monetary compensation in spite of the fact that the provision breached did not confer a right directly upon her. As this statement has only been made obiter, it is not yet clear whether this is a trend which signifies a change of approach on the part of the Court of Justice. It has been argued $^{76}$ that the lack of a clear stance on the possibility for individuals to claim compensation for breaches of EU environmental law has been remedied by the adoption of the Environmental Liability Directive which is aimed at preventing and repairing environmental damage. ${ }^{77}$

\section{THE FUTURE OF ENFORCEMENT OF EU ENVIRONMENTAL LAW: NEW METHODS, NEW ACTORS ... NEW TRENDS?}

In light of the shortcomings of both centralized and decentralized enforcement systems to secure the effective enforcement of EU environmental law and policy, a range of new initiatives have emerged to complement these classic EU law enforcement mechanisms. This new strategy can be considered as an exemplification of 'new governance' ${ }^{78}$ which is not solely typical

\footnotetext{
74 Prechal and Hancher, n 66, 108.

75 Case C-201/02 Wells [2004] ECR I-723.

76 Michael Dougan, National Remedies before the Court of Justice: Issues of Harmonisation and Differentiation (Hart, 2004) 45.

77 Dir 2004/35 of the European Parliament and the Council of 21 April 2004 on environmental liability with regard to the prevention and remedying of environmental damage [2004] OJ L143/56.

78 See further on this, Grainne de Búrca and Joanne Scott, Law and New Governance in the EU and the US (Hart Publishing 2006). Specifically on environmental law, see Ingmar von Homeyer, 'Emerging Experimentalism in EU Environmental Governance', in Charles F. Sabel and Jonathan Zeitlin (Eds), Experimentalist Governance in the European Union: Towards a New Architecture (Oxford University Press 2010) 121-50; Neil Gunningham, 'Environmental Law, Regulation and Governance: Shifting Architectures' (2009) JEL 179.
} 
of environmental policy. Broadly speaking, three main features distinguish 'new governance' from traditional forms of EU law-making: first, its emphasis on flexibility over strict command-and-control methods and the use of soft law over binding legislation; second, its collaborative nature and the inclusion of a range of private and public actors in the decisionmaking process; third, its responsiveness and adaptive capacity, thanks to the importance attached to information and knowledge generation. ${ }^{79}$

Whilst binding rules imposing requirements for licences, setting standards for inspections and providing judicially enforceable prohibitions still constitute the backbone of the EU's 'enforcement style' in this particular policy area, it is the EU institutions themselves, and in particular the Commission, which have promoted the use of new governance tools aimed at assisting in the prevention of breaches by Member States ${ }^{80}$ In the following section, two examples of these 'new governance' initiatives will be discussed, namely the use of soft law and networked enforcement. Their usefulness towards a more effective enforcement of EU environmental law will be examined.

\subsection{The Emergence of 'Soft Law' as an Enforcement Tool}

Environmental law is certainly one of the EU policy fields which has seen a burgeoning use of soft law measures. Virtually every area of environmental law has seen the emergence of guidance documents, mostly authored by the Commission, and often in cooperation with Member States. The virtues and vices of soft law have been extensively elaborated elsewhere ${ }^{81}$ In the context of enforcement, guidance documents can play an important role in ensuring the effective and coherent implementation of EU measures. ${ }^{82}$ By indicating how the Commission will make use of its

79 Maria Lee, EU Environmental Law, Governance and Decision-Making (Hart 2014) 81 .

80 See, for instance, the Commission Communication on 'Implementing European Community environmental law' $\operatorname{COM(2008)} 773$ final, n 26. In this Communication, the Commission advocated the need to use exchanges of information and expertise as a way to resolve implementation and enforcement issues.

81 Linda Senden, 'Soft Post-Legislative Rulemaking: A Time for More Stringent Control' (2013) ELJ 57; Joanne Scott, 'In Legal Limbo: Post-Legislative Guidance as a Challenge for European Administrative Law' (2011) CLMRev 329; Ingmar von Homeyer, 'Emerging Experimentalism in EU Environmental Governance', n 78, 121-50; Joanne Scott and David M. Trubek, 'Mind the Gap: Law and New Approaches to Governance in the European Union' (2002) ELJ $1-18$.

82 Linda Senden, Soft Law in European Community Law (Hart 2004) 146-8, $151-2$. 
enforcement powers or interpret certain rules, Member States can adapt their own behaviour (or that of their national authorities) where necessary. Moreover, it has been argued that post-legislative guidance may have the function of 'reassuring' the national authorities that they are acting in compliance with the law, at least those that act in accordance with it. ${ }^{83}$ Guidance documents may be useful in preventing infringement proceedings in the first place since national authorities may correct existing instances of non-compliance of their own motion, when, for example, infringements are not intentional.

From the perspective of the Commission, guidance documents may help the Commission substantiate a breach of an underlying norm. Specifically in the field of environmental policy, it has been shown that where legislative provisions are complex or open (in that they provide for vague standards such as the 'good water status' contained in the Water Framework Directive), guidance documents prove useful for the Commission in infringement proceedings since it is in these situations that conflicting interpretations of a norm are more likely to occur. Guidance documents which are agreed in a collaborative way by the Commission and Member States working together are particularly useful in infringement proceedings. When an understanding of a vague term is agreed upon, Member States are less likely to challenge these understandings in infringement proceedings. ${ }^{84}$

In the field of environmental law, two important examples of soft law are the Best Available Techniques Reference Documents (BREFs) adopted in the context of the Industrial Emissions Directive (IED) ${ }^{85}$ and the Guidance Documents issued in the framework of the Water Framework Directive (WFD). ${ }^{86}$ The BREFs ${ }^{87}$ provide guidance on the application of the best available techniques for categories of industrial activities listed in Annex I

83 See Scott, 'In Legal Limbo: Post-Legislative Guidance as a Challenge for European Administrative Law', n 81, 330, specifically in the area of environmental law.

84 Emilia Korkea-aho, 'Watering Down the Court of Justice? The Dynamics between Network Implementation and Article 258 TFEU Litigation' (2014) ELJ 664-5.

85 Dir 2010/75 of the European Parliament of 24 November 2010 on industrial emissions (integrated pollution prevention and control) [2010] OJ L334/17. Further on this, Maria Lee, EU Environmental Law, Governance and DecisionMaking, n 79, 108.

86 Dir 2000/60 of the European Parliament and of the Council of 23 October 2000 establishing a framework for Community action in the field of water policy [2000] OJ L327/1.

${ }^{87}$ All BREFs are retrievable online, on <http://eippcb.jrc.ec.europa.eu/refer ence/> accessed 10 December 2010. 
to the IED and serve to fill in the vague requirement of having to apply the 'best available techniques' (BAT) when national authorities have to issue permits for the industrial activities covered by the Directive. The BREFs thus may be considered as serving the purposes of a better enforcement of EU environmental law by providing a 'framework' within which national authorities can be reassured that they are acting in conformity with EU law.

As an instrument containing open-ended concepts such as 'good water status' ${ }^{88}$ the WFD requires subsequent specifications for the purpose of its implementation. To this end, several guidance documents have been elaborated with the aim of providing technical and scientific support for the Member States in the implementation of the WFD: 'They embody an impressive number of technical specifications, clarifications and recommendations on a variety of issues pertinent to implementation of the WFD' ${ }^{89}$ Once again, it can be argued that guidance documents lead to better enforcement of environmental law as they provide Member States with detailed information on how to act in accordance with the WFD and therefore avoid infringement proceedings.

As with all soft law measures, both the BREFs and the Guidance Documents issued under the WFD are not legally binding in the formal sense, but nevertheless can have important practical and legal effects. ${ }^{90}$ Under the predecessor of the IED, namely the IPPC Directive, the BREFs constituted non-binding guidance only. ${ }^{91}$ The BREFs themselves expressly stated that they do not set legally binding standards and are designed to give guidance information for industry, Member States and the public. ${ }^{92}$ The non-binding nature of the BREFs was confirmed by the Court. ${ }^{93}$ Nevertheless, the later IED enhanced the status of the BREFs

88 See Article 4, of Dir 2000/60, n 86.

89 Korkea-aho, 'Watering Down the Court of Justice? The Dynamics between Network Implementation and Article 258 TFEU Litigation', n 84, 656.

90 Senden, 'Soft Post-Legislative Rulemaking: A Time for More Stringent Control', n 81, 57; Scott, 'In Legal Limbo: Post-Legislative Guidance as a Challenge for European Administrative Law', n 81, 329.

91 It was indeed sufficient if Member States ensured that the competent authorities take account of 'the general principles [. . . when they determine the conditions of the permit'. See Article 3(2) of Dir 2008/1 of the European Parliament and the Council of 15 January 2008 concerning integrated pollution prevention and control [2008] OJ L24/8.

92 See e.g. the BREF on the intensive rearing of poultry and pigs (version of 2003), n 87, 274.

93 Case C-473/07 Association nationale pour la protection des eaux et rivièresTOS and Association OABA v Ministère de l'Ecologie, du Développement et de l'Aménagement durables [2009] ECR I-319, para 30. 
and made a specific part of the BREFs, the (BAT) conclusions, 'the reference' for the permitting framework, rather than one factor to be taken into consideration. ${ }^{94}$ This means that the BAT conclusions now contain legally binding standards with which Member States need to adhere and from which derogations can be invoked only in limited circumstances. ${ }^{95}$ The 28 Guidance Documents produced under the WFD are, on the other hand, still of non-binding force, but they constitute a powerful tool to give flesh to the vague notions of the WFD.

Whether guidance documents enhance the effective enforcement of EU environmental law is not an easy question to answer. Political scientists have acknowledged that 'in spite of strong normative assumptions regarding the alleged effectiveness of soft law forms of regulation to facilitate better regulation in heterogeneous environmental regimes, the actual capacity of novel regulatory approaches is rarely being addressed in a systematic way'. ${ }^{96}$ There is thus a lack of empirical evidence as to the actual usefulness of guidance documents which should be tackled in future research. An empirical study conducted on the application of the IPPC Directive, the predecessor of the IED, in four countries has shown, for example, that the effectiveness of guidance documents is strongly dependent on a number of factors including the material and cognitive resources available in terms of the administrative capacity and knowledge and expertise on the functioning of the Directive by national authorities and business actors, mutual trust amongst the stakeholders involved and credible national and EU pressure. ${ }^{97}$

\subsection{Networked Implementation and Enforcement}

A second tool of 'new governance' which has found application in the environmental field is that of networks, both in the application and in the enforcement phases. Networks stress the collaborative nature of "new governance' initiatives aimed at creating horizontal links between actors at different levels and/or different jurisdictions. As such governance networks may be described as structures of autonomous actors who are in

94 Article 14(3) of Dir 2010/75, n 85. For a discussion on the new status of the BREFs under the IED Directive, see Maria Lee, EU Environmental Law, Governance and Decision-Making, n 79, $119 \mathrm{ff}$.

95 See Article 15(3) and (4) of Directive 2010/75, n 85.

96 Charalampos Koutalakis, Aron Buzogany and Tanja A. Börzel, 'When Soft Regulation Is Not Enough: The Integrated Pollution Prevention and Control Directive of the European Union' (2010) Regul Gov 331.

97 Ibid, 339-40. 
a relationship of interdependence and horizontal cooperation for the sake of achieving common public goals. ${ }^{98}$ The literature on networks is vast and several attempts have been made at categorizing networks according to, for example, their membership, function and level of formality ${ }^{99}$ The Commission has showed itself very fond of 'network governance' and has in several official documents stressed the importance of networks for the implementation of EU law. ${ }^{100}$ The added value of networks is expected to be manifold and has been elaborated on extensively before and need not be discussed in depth here. ${ }^{101}$ Suffice to say that amongst the many advantages of this form of cooperation, networks are capable of bringing together knowledge and expertise that single actors may not possess. ${ }^{102}$ Furthermore, they may enable learning experiences for networks participants. ${ }^{103}$

In the field of environmental law, again the WFD and the IED can be regarded as good examples of instruments which entail the creation of 'network-like' structures for the implementation of EU law. In the framework of the WFD, the Common Implementation Strategy (CIS) provides for a joint approach in the implementation of the WFD with networks of experts which include national and EU level authorities as well as experts and stakeholders. It is explicitly aimed at 'allow[ing], as far as possible, a coherent and harmonious implementation of the framework directive' ${ }^{104}$ For this purpose, the CIS has been responsible for 'clarify[ing] and develop[ing], where appropriate, supporting technical

98 E.g. Tanja Börzel and Karen Heard-Laureote, 'Networks, EU Multi-Level Governance: Concepts and Contributions' (2009) JPP 137.

99 See e.g. Eva Sørensen and Jacob Torfing, 'Governance Network Research: Towards a Second Generation', in Sørensen and Torfing (Eds), Theories of Democratic Network Governance (Palgrave-Macmillan 2007) 1-21.

100 See e.g. Commission of the European Communities, 'Report to the Council and to the European Parliament on cooperation between administrations for enforcement of internal market law: a progress report' $\operatorname{COM}(96) 20$ final; European Commission, 'European Governance: A White Paper' COM(2001) 428 final.

101 For an overview, see Chapter 4 in this volume.

102 Eva Sørensen and Jacob Torfing, 'The Democratic Anchorage of Governance Networks' (2005) SPS 198-9.

103 James S. Mosher and David M. Trubek, 'Alternative Approaches to Governance in the EU: EU Social Policy and the European Employment Strategy' (2003) J Com Mar St 76-7.

104 'Common Implementation Strategy for the Water Framework Directive (2000/60/EC)', Strategic Document as agreed by the Water Directors under Swedish Presidency, 2 May 2001, 2, accessed 10 December 2015 at <http:// ec.europa.eu/environment/water/water-framework/objectives/pdf/strategy.pdf>. 
and scientific information to assist in the practical implementation of the Directive' 105 and it provides a forum for exchange of best practices and experiences in implementation. One of the most important tasks of CIS has been to develop the guidance documents mentioned above. Also, it seems to have been useful for the Commission for gathering information which has subsequently been used in infringement proceedings. ${ }^{106}$

In addition, the IED features an interesting system of cooperation linked to the so-called 'Seville process' aimed at identifying the 'best available techniques' standards. This process evolved initially outside the framework of the IPPC Directive, the predecessor to the IED. It has now been formalized under Article 13 of the IED. The Seville process is managed by the European IPPC Bureau, which carries out its work through Technical Working Groups (TWGs). These informal groups which comprise technical experts representing Member States, industries, environmental organizations and the Commission are set up by the Commission for the development and review of the BREFs mentioned above. ${ }^{107}$ In addition to the exchange of information that takes place within the TWGs, the IED imposes an obligation on the Commission to establish and convene a 'Forum' which is to be composed of 'representatives of Member States, the industries concerned and non-governmental organizations promoting environmental protection'. ${ }^{108}$ Its main task is to provide an opinion of the content of the BREFs proposed by the TWGs. ${ }^{109}$ This form of collaborative governance has been regarded as providing 'crucial information and knowledge from a range of sources, and open[ing] up the possibility of shared problem-solving'. ${ }^{110}$ The information sharing and problem-solving platform created by the Seville process may lead in turn to better application and enforcement of EU law. It allows national authorities to profit from each other's experiences with regards to compliance problems and to decide on mutually agreed solutions on how to tackle certain compliance failures uniformly.

Both of the network structures discussed above have the prime function of developing guidance documents which themselves are designed to help

\footnotetext{
105 Ibid.

106 Korkea-aho, 'Watering Down the Court of Justice? The Dynamics between Network Implementation and Article 258 TFEU Litigation', n 84, 662.

107 An interesting analysis of the BREF Documents drafting process was carried out by Bettina Lange, 'From Boundary Drawing to Transition Points: The Creation of Normativity under the IPPC Directive' (2002) ELJ 226-46.

108 Article 13(3) of the IED Directive.

109 Article 13(4) of the IED Directive.

110 Lee, EU Environmental Law, Governance and Decision-Making, n 79, 114.
} 
implementation of EU environmental law. However, their virtues lie also in their very existence since they provide a forum for national authorities to exchange ideas, develop best practices and create a sense of mutual learning which may ultimately improve the implementation of environmental law. In other words, there may be fringe benefits for authorities participating in these networks next to the prime 'products' created by these networks. ${ }^{111}$

Finally, in the framework of environmental law, mention must be made of a network which is specifically aimed at tackling enforcement issues, the European Union Network for the Implementation and Enforcement of Environmental Law (IMPEL). Originally created in 1992 as an informal forum for the exchange of information and experience without any formal involvement on the part of the EU, IMPEL has become progressively more embedded in the EU institutional framework with a Secretariat located within the Commission's Directorate General for Environment. ${ }^{112}$ The purpose of IMPEL is 'to create the necessary impetus in the [EU] to make progress on ensuring a more effective application of environmental legislation'. ${ }^{113}$ It aims at achieving this purpose by, amongst others, promoting the exchange of information and experiences between environmental authorities on the implementation of EU environmental law; identifying and developing best practices; and producing guidance, tools and common standards. Recently it also started to act as the Commission's advisor on how environmental legislation may be drafted so as to be made easier to implement. ${ }^{114}$

Political science research suggests that it is in particular those networks that are perceived by the network participants themselves as allowing for informal cooperation that may be useful for supporting national administrations in the implementation of EU law. Networks facilitate mutual learning and mutual trust, promote conflict resolution and allow for resource sharing. As a result, they play an important role in improving the application and enforcement of EU law. ${ }^{115}$

\footnotetext{
111 See further Chapter 4 of this volume.

112 Maria Martens, 'Administrative Integration through the Back Door? The Role and Influence of the European Commission in Transgovernmental Networks within the Environmental Policy Field' (2008) J Europ Integration 644.

113 See $<$ http://impel.eu/about/history/> accessed 10 December 2015.

114 Martens, 'Administrative Integration through the Back Door? The Role and Influence of the European Commission in Transgovernmental Networks within the Environmental Policy Field', n 112, 640-41. For some critical remarks on this latter role, see Hedemann-Robinson, Enforcement of European Union Environmental Law: Legal Issues and Challenges, n 18, 462-5.

115 See Chapter 4 of this volume.
} 
The role of IMPEL in the context of EU environmental law, is no exception.

\section{CONCLUSION}

The EU's 2013-20 Environmental Action Programme acknowledges the serious implementation gap which concerns EU environmental law ${ }^{116}$ and stipulates that '[i]mproving the implementation of the Union environment acquis at Member State level will therefore be given top priority in the coming years' ${ }^{117}$ In order to do so the EU has pledged to ensure that by 2020 'the principle of effective legal protection for citizens and their organizations is facilitated' through making sure that national provisions on access to justice comply with the case law of the CJEU. ${ }^{118}$ This chapter reveals that whilst the shortcomings of the infringement proceedings make reliance on the decentralized enforcement of EU law through national courts and NGOs a necessity for the EU, there are currently still several legal gaps and constitutional obstacles which natural and legal persons have to face at national level when enforcing violations of EU environmental law. First of all, the specific nature of environmental law and its protection of diffuse rather than individual interests demonstrates the crucial role played by NGOs in the enforcement of EU environmental law where individuals would not have the legal possibility or the interest to pursue legal proceedings. The need to ensure wide access to justice for citizens and such organizations in environmental matters is recognized at international level and is an obligation mandated by Articles 9(2) and (3) of the UN's Aarhus Convention. Overall, the transposition of Article 9(2) into the national laws of the Member States by virtue of Directive 2003/35 has been successful. Gaps in its implementation by the Member States have been corrected following several preliminary rulings of the CJEU. Nevertheless, a gap still remains as far as Article 9(3) is concerned. Political consensus could not be reached on the scope of transposition measures. This has left national legal conditions of access to courts throughout the EU intact (and potentially divergent). To some extent, the resulting uncertainties and inequalities have been remedied by the rulings of the CJEU which has imposed an

116 Dec 1386/2013 of the European Parliament and of the Council of 20 November 2013 on a General Union Environment Action Programme to 2020 'Living well, within the limits of our planet', n 5, para 56.

117 Ibid, para 57.

118 Ibid, para 65(e) and (v). 
important duty on the national courts to ensuring that the requirements of the Aarhus Convention are respected through the application of the principle of consistent interpretation. This chapter submits that the necessary legal certainty and level playing field can only be achieved through clear legislative intervention to harmonize national standing rules for NGOs' claims and by setting criteria which are to be applied EU-wide. The CJEU, using the preliminary reference mechanism, can then contribute to the interpretation of the relevant legislative provisions. However, it cannot be considered as a self-standing alternative to legislative intervention given the case-by-case nature of the intervention, and the necessary reliance on the national court's willingness to question their own national law.

Even when access to court is granted to natural and legal persons, a further obstacle lies in the ability of individuals to enforce EU law before national courts through the doctrines of direct effect and state liability. Whilst the case law of the CJEU has extended somewhat the possibility of relying on the direct effect of EU environmental norms in circumstances where the requirement of the conferral of a right by the infringed provision has not been met, the absence of rights in several EU environmental provisions is still a hurdle for individuals seeking to bring damages claims based on the principle of state liability.

The future of the enforcement of EU environmental law lies not just in typical command-and-control systems. New tools and new mechanisms based on non-binding measures, collaborative networks, and collecting and sharing information have gradually acquired greater prominence in the field of environmental law. This chapter has examined two examples of these 'new' modes of governance, namely guidance documents and networks, and has shown that they present several advantages for the effective enforcement of EU environmental law. The 2013-20 Environmental Action Programme demonstrates the priority that the EU attaches to information gathering and spreading, and cooperation between different administrative levels, with the IMPEL network being mentioned explicitly as a way to foster better implementation of EU environmental law. ${ }^{119}$ The Commission seems therefore to show a preference for a combination of judicially enforceable rules (and the necessity to create an adequate judicial enforcement framework) with softer, more cooperative ways to achieve compliance with EU environmental law. Yet, whilst this chapter demonstrates that networks and guidance documents represent a promising addition to the more traditional instruments, further legal and political

119 Ibid, para 63. 
academic attention should be devoted to exploring their actual effectiveness (and the conditions for their effectiveness) in order to promote a higher level of compliance with EU environmental law. 